\title{
Increasing zinc levels in phytase-supplemented diets improves the performance and nutrient utilization of broiler chickens
}

\author{
M. Akter ${ }^{1 \#}$, P. A. lji ${ }^{1} \&$ H. Graham ${ }^{2}$ \\ School of Environmental and Rural Science, University of New England, Armidale, NSW 2351, Australia \\ AB Vista, 3 Woodstock Court, Marlborough, Wilts SN8 4AN, UK
}

(Received 30 May 2017; Accepted 9 August 2017; First published online 2 September 2017)

\begin{abstract}
Copyright resides with the authors in terms of the Creative Commons Attribution 4.0 South African License.
See: http://creativecommons.org/licenses/by/4.0/za

Condition of use: The user may copy, distribute, transmit and adapt the work, but must recognize the authors and the South African Journal of Animal Science.
\end{abstract}

\begin{abstract}
Three hundred and thirty-six day-old Ross-308 male broiler chicks were used in a 35-day trial to investigate the effect of different concentrations of dietary $\mathrm{Zn}$ and phytase on broiler performance and energy utilization. Twelve day-old birds were used for the initial slaughter group to provide baseline body compositional data, while the remaining 324 birds were randomly distributed to six experimental diets. The treatments consisted of a $3 \times 2$ factorial arrangement with three levels of $\mathrm{Zn}$ (low, mid, and high; 30, 40, and $50 \mathrm{mg} / \mathrm{kg}$, respectively) and two levels $(0,500 \mathrm{FTU} / \mathrm{kg})$ of microbial phytase. Each dietary treatment was fed to 6 cages (9 birds/cage). Low Zn diet significantly decreased feed intake and body weight gain at days 1-24. Phytase supplementation improved body weight gain at $\mathrm{d} 24$, irrespective of $\mathrm{Zn}$ level. The digestibility of $\mathrm{P}$ was improved in birds fed high-Zn diet with phytase supplementation, and the reverse was the case for $\mathrm{Fe}$ and $\mathrm{Zn}$ digestibility. High dietary $\mathrm{Zn}$ increased the $\mathrm{Zn}$ and Fe deposition in liver. The activity of AP, CaATPase and Mg-ATPase in the jejunum was high in the phytase supplemented mid-level $\mathrm{Zn}$ diet. Phytase supplemented to the mid and high level Zn diets significantly improved most energy utilization parameters. This result indicate that the $\mathrm{Zn}$ concentrations used in this study were not inhibitory to phytase activity and broiler performance. Therefore, it can be concluded that dietary zinc level in phytase-supplemented diets could be increased up to $50 \mathrm{mg} / \mathrm{kg}$ without any negative effect on phytase-mediated broiler response.
\end{abstract}

Keywords: Bone quality, net energy, nutrient utilization

\#Corresponding author: marjinajahivet@gmail.com

\section{Introduction}

Zinc is an important trace mineral which plays a vital role in growth, feathering and disease resistance of chickens (Ao et al., 2011). A deficiency of $\mathrm{Zn}$ may cause retardation in growth, bone malformations, and suppression of disease resistance due to its essential role as a co-factor of many enzymes (Kfoury et al. 1968, Underwood \& Suttle, 1999a). Although the NRC (1994) recommended $40 \mathrm{mg} \mathrm{Zn/kg}$ of diet, most commercial broiler diets are formulated to contain $100-120 \mathrm{mg} \mathrm{Zn} / \mathrm{kg}$. This excess of $\mathrm{Zn}$ in diets is ultimately excreted through the droppings and can pose a significant threat to the environment and crop production (Burrell et al., 2004). However, most $\mathrm{Zn}$ is bound with phytic acid. Despite a sufficient level of $\mathrm{Zn}$ in maizesoybean meal based-diets, the presence of fibre or phytate limits bioavailability in chickens (Underwood \& Suttle, 1999).

Phytate forms complexes with different cations, such as $\mathrm{Ca}, \mathrm{P}, \mathrm{Zn}, \mathrm{Fe}$ and $\mathrm{Cu}$, and reduces their bioavailability in chickens (Maenz et al., 1999). Due to its high affinity for phytate, $\mathrm{Zn}$ forms a strong insoluble $\mathrm{Zn}$-phytate complex (Reddy et al., 1982), which impairs the availability of $\mathrm{Zn}$ in chickens and can result in poor growth (O'Dell \& Savage, 1960). Supplementation with microbial phytase has proved to be effective in dephosphorylating phytate and releasing the phytate-bound minerals (Kornegay, 2001). A previous in vitro study showed that incereased level of Zn $(50 \mathrm{mg} / \mathrm{kg}$ ) reduced phytate hydrolyis by phtyase (Akter et al., 2015).

Inclusion of phytase in maize-soybean-based diets containing low (5 ppm) Zn improved the body weight gain and feed intake of chickens (Yi et al., 1996b). Ao et al. (2007) found that supplementing phytase to diets with $12 \mathrm{mg} \mathrm{Zn/kg}$ resulted in increased feed intake and weight gain. In contrast, Mohanna and Nys (1999a) observed no significant difference in weight gain, feed intake and tibia ash content of birds fed diets 
containing 10 and $30 \mathrm{mg} \mathrm{Zn/kg}$ with or without phytase. Other researchers have reported that including phytase in chicken diets improves the availability of Zn (Thiel et al., 1993; Roberson \& Edwards, 1994; Yi et al., 1996a), while the effect of a lack of phytase on $\mathrm{Zn}$ retention has also been reported in other studies (Roberson \& Edwards, 1994; Sebastian et al., 1996). The lack of agreement between these studies may be the result of using different concentrations of $\mathrm{Zn}$ and phytase in diets, because, in addition to using varying levels of phytase, the concentrations of $\mathrm{Zn}$ in the experimental diets of these studies were either below the NRC (1994) recommendation for growth $(40 \mathrm{mg} / \mathrm{kg})$ or above the recommendation for maximum tissue deposition $(85 \mathrm{mg} / \mathrm{kg}$ ) (Mohanna \& Nys, 1999b). Therefore, the present study was undertaken to evaluate the effect of different levels of $\mathrm{Zn}$ on phytase activity and impact on broiler growth performance, bone development, and nutrient utilization.

\section{Materials and methods}

The experiment was undertaken at the Centre for Animal Research and Teaching (CART) of the University of New England (UNE), Australia. All the procedures used in this study were approved by the Animal Ethics Committee of the same University (Approval No: AEC14-120).

The overall methodology that was adopted in this study has already been documented in Akter et al. (2017). However, a total of 336 day-old Ross 308 male broiler chicks $(40.0 \pm 0.7 \mathrm{~g})$ were obtained from a local commercial hatchery (Baiada Poultry Pty. Ltd., Tamworth, Australia). On day one, 324 chicks were immediately randomly allocated to 6 treatments, with 54 chicks in each. Each treatment had six replicates with nine birds per replicate cage. The remaining 12 birds were used for the initial slaughter group, to provide baseline body compositional data.

Six experimental diets were formulated with low, mid, and high levels of $\mathrm{Zn}(30,40$, and $50 \mathrm{mg} / \mathrm{kg}$, respectively) with $500 \mathrm{FTU} / \mathrm{kg}$ or without exogenous microbial phytase (Tables 1,2 and 3 ). All diets were formulated either to meet or exceed the Aviagen (2009) nutrient recommendations and breed standards, with the exception of $\mathrm{Zn}$. Diets were iso-energetic and iso-nitrogenous. In all grower diets, titanium dioxide $\left(\mathrm{TiO}_{2}\right)$, was added as an indigestible marker. The $\mathrm{Ca}, \mathrm{AvP}$ and $\mathrm{Na}$ levels in the phytase-supplemented diets were calculated to include the mineral matrix $(1.5 \mathrm{~g}$, AvP, $1.65 \mathrm{~g} \mathrm{Ca}$, and $0.35 \mathrm{~g} \mathrm{Na}$ per $\mathrm{kg}$ of diet) of the commercial Escherichia coli-derived phytase product used (Quantum Blue, AB Vista, Marlborough, UK). The activity of the phytase product was $5000 \mathrm{U} / \mathrm{g}$ where a unit (FTU) is defined as the quantity of enzyme that liberates one $\mu \mathrm{mol}$ of inorganic $\mathrm{P}$ per minute from sodium phytate at $\mathrm{pH} 5.5$ and $37^{\circ} \mathrm{C}$. After mixing, the diets were pelleted at $65^{\circ} \mathrm{C}$ temperature. The diets were fed to the birds as starter $(0-10 \mathrm{~d})$, grower $(11-24 \mathrm{~d})$, and finisher $(25-35 \mathrm{~d})$.

The collection, processing and chemical analysis of different samples (diets, ileal digesta, excreta, tibia bones, liver and part of jejunum) have been described previously (Akter et al., 2017).

On d 24, two birds from each replicate were killed and the whole intact carcases were frozen immediately and later processed. Both chicks from the same cage were pooled and processed together. After chopping and coarse-grinding individual chickens, they were thoroughly mixed and two subsamples (approximately $200 \mathrm{~g}$ each, wet weight) were finely ground and freeze-dried as described by Olukosi et al. (2008). The two subsamples were mixed together after drying, and ground again, from which a smaller subsample was taken for chemical analysis. The ground carcase samples were analysed for gross energy (GE), diethyl ether extractable fat $(\mathrm{EE})$ and nitrogen $(\mathrm{N})$.

The nitrogen content of the diets and meat samples was determined according to the Dumas combustion technique, as described by Sweeney (1989) using a LECO® FP-2000 automatic nitrogen analyser (Leco FP analyser model 602600; Leco Corp., St Joseph, Michigan, USA) with EDTA as a calibration standard. The crude protein (CP) equivalent of the ingredients was calculated as $N(\%) \times 6.25$. The EE was determined indirectly by the Soxhlet method for fat extraction. Around 6-8 g of finely ground sample was weighed into pre-weighed filter paper (No1 Whatman $185 \mathrm{~mm}$ ) and extracted for 48 to 50 hours with chloroform, using a Soxhlet apparatus. After that, the samples were allowed to drain and dry at $80{ }^{\circ} \mathrm{C}$ for 72 hours. The EE was calculated as loss in weight and expressed as a proportion of dried sample weight.

To calculate the apparent metabolizable energy (AME), the following formulae were used:

$$
\operatorname{AME}(\mathrm{MJ} / \mathrm{kg})=\mathrm{GEi}-[\text { GEo } \times(\mathrm{Ti} / \mathrm{To})]
$$

where: GEi is gross energy $(\mathrm{MJ} / \mathrm{kg})$ in feed;

GEo is the gross energy $(\mathrm{MJ} / \mathrm{kg})$ in excreta,

$\mathrm{Ti}$ is the concentration of titanium dioxide in the diets; and

To is the concentration of titanium dioxide in the excreta. 
Table 1 Ingredient and nutrient specifications of starter ( 0 - 10 days) diets

\begin{tabular}{|c|c|c|c|c|c|c|}
\hline \multirow{2}{*}{$\begin{array}{l}\text { Ingredient composition } \\
(\mathrm{g} / \mathrm{kg})\end{array}$} & \multicolumn{3}{|c|}{ Without phytase } & \multicolumn{3}{|c|}{ With phytase } \\
\hline & Low Zn & Mid Zn & High Zn & Low Zn & Mid Zn & High Zn \\
\hline Maize & 570.1 & 569.8 & 569.5 & 586.7 & 586.9 & 586.6 \\
\hline Soybean meal & 338.0 & 338.0 & 338.1 & 336.2 & 336.2 & 336.3 \\
\hline Meat meal & 24.6 & 24.7 & 24.7 & 23.7 & 23.7 & 23.7 \\
\hline Canola oil & 26.4 & 26.5 & 26.6 & 21.0 & 21.0 & 21.1 \\
\hline Limestone & 11.2 & 11.2 & 11.2 & 11.5 & 11.5 & 11.5 \\
\hline Dicalcium phosphate & 15.1 & 15.1 & 15.1 & 7.3 & 7.3 & 7.3 \\
\hline Salt & 1.7 & 1.7 & 1.7 & 2.0 & 2.0 & 2.0 \\
\hline Sodium bicarbonate & 2.0 & 2.0 & 2.0 & 0.4 & 0.4 & 0.4 \\
\hline Premix $^{A}$ & 2.0 & 2.0 & 2.0 & 2.0 & 2.0 & 2.0 \\
\hline Choline $\mathrm{Cl}$ & 0.9 & 0.9 & 0.9 & 1.1 & 0.9 & 0.9 \\
\hline L-lysine $\mathrm{HCl}$ & 3.0 & 3.0 & 3.0 & 3.0 & 3.0 & 3.0 \\
\hline DL-methionine & 4.1 & 4.1 & 4.1 & 4.1 & 4.1 & 4.1 \\
\hline L-threonine & 1.9 & 1.9 & 1.9 & 1.9 & 1.9 & 1.9 \\
\hline Phytase & - & - & - & 0.01 & 0.01 & 0.01 \\
\hline \multicolumn{7}{|c|}{ Calculated nutrient composition $(\mathrm{g} / \mathrm{kg})^{2}$} \\
\hline Calcium & 10.5 & 10.5 & 10.5 & 10.5 & 10.5 & 10.5 \\
\hline Available phosphorus & 5.0 & 5.0 & 5.0 & 5.0 & 5.0 & 5.0 \\
\hline Total phosphorus & 7.4 & 7.4 & 7.4 & 5.9 & 5.9 & 5.9 \\
\hline Sodium & 1.6 & 1.6 & 1.6 & 1.6 & 1.6 & 1.6 \\
\hline Zinc (mg/kg) & 30 & 40 & 50 & 30 & 40 & 50 \\
\hline \multicolumn{7}{|c|}{ Analysed nutrient composition ( $\mathrm{g} / \mathrm{kg}$ ) } \\
\hline Calcium & 11.6 & 11.5 & 11.1 & 11.8 & 12.0 & 11.5 \\
\hline Total phosphorus & 7.5 & 8.6 & 7.5 & 6.9 & 6.3 & 6.0 \\
\hline Sodium & 1.6 & 1.8 & 1.7 & 1.5 & 1.6 & 1.4 \\
\hline Zinc (mg/kg) & 36 & 45 & 58 & 35 & 43 & 55 \\
\hline Phytase FTU/kg & 29 & 35 & 27 & 534 & 540 & 530 \\
\hline
\end{tabular}

\footnotetext{
'Supplied per $\mathrm{kg}$ of diet $(\mathrm{mg}): 3.6 \mathrm{mg}$ vitamin A (as all-trans retinol); $0.09 \mathrm{mg}$ cholecalciferol; $44.7 \mathrm{mg}$ vitamin E (as d- $\alpha$ tocopherol); $2 \mathrm{mg}$ vitamin $\mathrm{K} 3 ; 2 \mathrm{mg}$ thiamine; $6 \mathrm{mg}$ riboflavin; $5 \mathrm{mg}$ pyridoxine hydrochloride; $0.2 \mathrm{mg}$ vitamin $\mathrm{B} 12 ; 0.1 \mathrm{mg}$ biotin; 50 mg niacin; 12 mg D-calcium pantothenate; 2 mg folic acid; 80 mg Mn; 60 mg Fe; 8 mg Cu; 1 mg I; 0.3 mg Co; 1 $\mathrm{mg} \mathrm{Mo.;}{ }^{2}$ All diets were formulated to contain $12.7 \mathrm{MJ} / \mathrm{kg}$ metabolisable energy; $220 \mathrm{~g} / \mathrm{kg}$ crude protein; $6.9 \mathrm{~g} / \mathrm{kg}$ digestible methionine, $12.7 \mathrm{~g} / \mathrm{kg}$ digestible lysine; $9.4 \mathrm{~g} / \mathrm{kg}$ digestible methionine + cysteine; $8.3 \mathrm{~g} / \mathrm{kg}$ digestible threonine, $13.7 \mathrm{~g} / \mathrm{kg}$ digestible arginine.
}

Net energy of production (NEp) was calculated as follows:

$$
\begin{aligned}
& \text { Initial GE of carcase }(\mathrm{kJ})=\text { carcase } \mathrm{GE}(\mathrm{kJ} / \mathrm{g}) \times \text { body weight of bird }(\mathrm{g}) \text {--- (1) } \\
& \text { Final GE content of carcase }(\mathrm{kJ})=\text { carcase } \mathrm{GE}(\mathrm{kJ} / \mathrm{g}) \times \text { body weight of bird }(\mathrm{g}) \text {--- (2) } \\
& \mathrm{NEp}(\mathrm{kJ})=(2)-(1)
\end{aligned}
$$


Table 2 Ingredient and nutrient specifications of grower (11 - 24 days) diets

\begin{tabular}{|c|c|c|c|c|c|c|}
\hline \multirow{2}{*}{$\begin{array}{l}\text { Ingredient composition } \\
(\mathrm{g} / \mathrm{kg})\end{array}$} & \multicolumn{3}{|c|}{ Without phytase } & \multicolumn{3}{|c|}{ With phytase } \\
\hline & Low Zn & Mid Zn & High Zn & Low Zn & Mid Zn & High Zn \\
\hline Maize & 598.2 & 597.9 & 597.6 & 615.1 & 614.8 & 614.5 \\
\hline Soybean meal & 282.0 & 282.1 & 282.1 & 280.2 & 280.2 & 280.3 \\
\hline Meat meal & 50.0 & 50.0 & 50.0 & 49.0 & 49.0 & 49.0 \\
\hline Canola oil & 38.7 & 38.8 & 38.9 & 33.2 & 33.3 & 33.4 \\
\hline Limestone & 6.3 & 6.3 & 6.3 & 6.6 & 6.6 & 6.6 \\
\hline Dicalcium phosphate & 7.9 & 7.9 & 7.9 & 0.0 & 0.0 & 0.0 \\
\hline Salt & 1.7 & 1.7 & 1.7 & 1.6 & 1.6 & 1.6 \\
\hline Na bicarbonate & 1.5 & 1.5 & 1.5 & 0.5 & 0.5 & 0.5 \\
\hline $\mathrm{TiO}_{2}$ & 5.0 & 5.0 & 5.0 & 5.0 & 5.0 & 5.0 \\
\hline Premix $^{1}$ & 2.0 & 2.0 & 2.0 & 2.0 & 2.0 & 2.0 \\
\hline Choline $\mathrm{Cl}$ & 1.0 & 1.0 & 1.0 & 1.0 & 1.0 & 1.0 \\
\hline L-lysine $\mathrm{HCl}$ & 1.9 & 1.9 & 1.9 & 2.0 & 2.0 & 2.0 \\
\hline DL-methionine & 3.4 & 3.4 & 3.4 & 3.4 & 3.4 & 3.4 \\
\hline L-threonine & 1.4 & 1.4 & 1.4 & 1.4 & 1.4 & 1.4 \\
\hline Phytase & - & - & - & 0.01 & 0.01 & 0.01 \\
\hline \multicolumn{7}{|c|}{ Calculated nutrient composition $(\mathrm{g} / \mathrm{kg})^{2}$} \\
\hline Calcium & 9.0 & 9.0 & 9.0 & 9.0 & 9.0 & 9.0 \\
\hline Available phosphorus & 4.5 & 4.5 & 4.5 & 4.5 & 4.5 & 4.5 \\
\hline Total phosphorus & 5.9 & 5.9 & 5.9 & 5.3 & 5.3 & 5.3 \\
\hline Sodium & 1.6 & 1.6 & 1.6 & 1.6 & 1.6 & 1.6 \\
\hline Zinc (mg/kg) & 30 & 40 & 50 & 30 & 40 & 50 \\
\hline \multicolumn{7}{|c|}{ Analysed nutrient composition (g/kg) } \\
\hline Calcium & 10.0 & 9.5 & 9.6 & 9.0 & 9.5 & 9.4 \\
\hline Total phosphorus & 7.6 & 7.3 & 7.1 & 6.0 & 6.1 & 5.9 \\
\hline Sodium & 1.7 & 1.7 & 1.9 & 1.8 & 1.6 & 1.5 \\
\hline Zinc (mg/kg) & 32 & 45 & 54 & 35 & 43 & 57 \\
\hline Phytase & 40 & 35 & 40 & 545 & 535 & 540 \\
\hline
\end{tabular}

${ }^{1}$ Composition as in Table1;

${ }^{2}$ All diets were formulated to contain $13.2 \mathrm{MJ} / \mathrm{kg}$ metabolisable energy; $210 \mathrm{~g} / \mathrm{kg}$ crude protein; $6.1 \mathrm{~g} / \mathrm{kg}$ digestible methionine, $11.0 \mathrm{~g} / \mathrm{kg}$ digestible lysine;8.4 g/kg digestible methionine + cysteine; $7.3 \mathrm{~g} / \mathrm{kg}$ digestible threonine, $12.6 \mathrm{~g} / \mathrm{kg}$ digestible arginine.

Heat production (HP), which consists of the heat increment of feeding and fasting HP, was calculated as the difference between NEp and ME intake (MEI):

$$
\mathrm{HP}(\mathrm{kJ})=\mathrm{MEI}-\mathrm{NEp}
$$

where, ME intake (MEI) was calculated using the following formula:

$\operatorname{MEI}(k J)=M E(k J / g) \times$ feed intake $(g)$

Energy retained as fat (REf) and as protein (REp) was calculated as follows:

$$
\begin{aligned}
& \operatorname{REf}(\mathrm{kJ})=\text { Carcase fat }(\mathrm{g}) \times 38.2 \mathrm{~kJ} / \mathrm{g} \\
& \operatorname{REp}(\mathrm{kJ})=\text { Carcase crude protein content }(\mathrm{g}) \times 23.6 \mathrm{~kJ} / \mathrm{g} .
\end{aligned}
$$


The values 38.2 and $23.6 \mathrm{~kJ} / \mathrm{g}$ are energy values per gram of fat and protein, respectively, as derived by Larbier and Leclercq (1992):

Efficiency of ME use for energy retention $(k R E)=N E p / M E I$

Efficiency of ME use for lipid retention $\left(k R E_{f}\right)=R E f / M E I$

Efficiency of ME use for protein retention $\left(k R E_{p}\right)=R E p / M E I$.

The data were analysed using a factorial model of the GLM of Minitab software (Minitab, 2010). The statistical model inlcuded the $\mathrm{Zn}$, phytase and their interacion effect. Differences within a significant effect were separated using Tukey's Honest Significance Difference test. Significant differences between diets were determined using Fisher's least significance difference test at $P \leq 0.05$.

Table 3 Ingredient and nutrient specifications of finisher (24 - 35 days) diets

\begin{tabular}{|c|c|c|c|c|c|c|}
\hline \multirow{2}{*}{$\begin{array}{l}\text { Ingredient composition } \\
(\mathbf{g} / \mathbf{k g})\end{array}$} & \multicolumn{3}{|c|}{ Without phytase } & \multicolumn{3}{|c|}{ With phytase } \\
\hline & Low Zn & Mid Zn & High Zn & Low Zn & Mid Zn & High Zn \\
\hline Maize & 630.7 & 630.4 & 630.1 & 628 & 628.2 & 628.4 \\
\hline Soybean meal & 257.8 & 257.8 & 257.9 & 282.8 & 282.1 & 281.4 \\
\hline Meat meal & 50.0 & 50.0 & 50.0 & 31.9 & 32.4 & 32.8 \\
\hline Canola oil & 39.7 & 39.8 & 39.9 & 39.5 & 39.5 & 39.4 \\
\hline Limestone & 6.0 & 6.0 & 6.0 & 7.9 & 7.8 & 7.8 \\
\hline Dicalcium phosphate & 6.4 & 6.4 & 6.4 & 1.8 & 1.7 & 1.6 \\
\hline Salt & 2.0 & 2.0 & 2.0 & 2.0 & 2.0 & 2.0 \\
\hline Na bicarbonate & 1.1 & 1.1 & 1.1 & 0.4 & 0.3 & 0.3 \\
\hline Premix $^{1}$ & 2.0 & 2.0 & 2.0 & 2.0 & 2.0 & 2.0 \\
\hline Choline $\mathrm{Cl}$ & 0.9 & 0.9 & 0.9 & 0.8 & 0.8 & 0.8 \\
\hline L-lysine $\mathrm{HCl}$ & 1.0 & 1.0 & 1.0 & 0.6 & 0.6 & 0.6 \\
\hline DL-methionine & 2.7 & 2.7 & 2.7 & 2.6 & 2.6 & 2.6 \\
\hline L-threonine & 0.8 & 0.8 & 0.8 & 0.7 & 0.7 & 0.7 \\
\hline Phytase & - & - & - & 0.01 & 0.01 & 0.01 \\
\hline \multicolumn{7}{|c|}{ Calculated nutrient composition $(\mathrm{g} / \mathrm{kg})^{2}$} \\
\hline Calcium & 8.5 & 8.5 & 8.5 & 8.5 & 8.5 & 8.5 \\
\hline Available phosphorus & 4.2 & 4.2 & 4.2 & 4.2 & 4.2 & 4.2 \\
\hline Total phosphorus & 6.4 & 6.4 & 6.4 & 5.0 & 5.0 & 5.0 \\
\hline Sodium & 1.6 & 1.6 & 1.6 & 1.6 & 1.6 & 1.6 \\
\hline Zinc $(\mathrm{mg} / \mathrm{kg})$ & 30 & 40 & 50 & 30 & 40 & 50 \\
\hline \multicolumn{7}{|c|}{ Analysed nutrient composition $(\mathrm{g} / \mathrm{kg})$} \\
\hline Calcium & 9.1 & 9.2 & 9.0 & 8.6 & 8.8 & 9.1 \\
\hline Total phosphorus & 6.5 & 6.5 & 6.5 & 5.0 & 5.0 & 5.0 \\
\hline Sodium & 1.9 & 1.6 & 1.8 & 1.5 & 1.6 & 1.5 \\
\hline Zinc (mg/kg) & 35 & 48 & 59 & 33 & 46 & 58 \\
\hline Phytase (U/kg) & 28 & 36 & 30 & 540 & 550 & 545 \\
\hline
\end{tabular}

\footnotetext{
${ }^{1}$ Composition as in Table 1;

${ }^{2}$ All diets were formulated to contain $13.4 \mathrm{MJ} / \mathrm{kg}$ metabolisable energy; $200 \mathrm{~g} / \mathrm{kg}$ crude protein; $5.3 \mathrm{~g} / \mathrm{kg}$ digestible methionine, $9.7 \mathrm{~g} / \mathrm{kg}$ digestible lysine; $7.6 \mathrm{~g} / \mathrm{kg}$ digestible methionine + cysteine; $6.5 \mathrm{~g} / \mathrm{kg}$ digestible threonine, $12.3 \mathrm{~g} / \mathrm{kg}$ digestible arginine.
} 


\section{Results}

The gross response of birds fed different levels of $\mathrm{Zn}$ and phytase is shown in Table 4. There was no significant interaction between $\mathrm{Zn}$ and Phytase for $\mathrm{FI}$ and BWG for birds at any stage of rearing. At d 10, feed intake $(\mathrm{Fl})$ decreased $(P<0.05)$ in birds on low-Zn diet. Phytase supplementation had no influence $(P$ $>0.05)$ on Fl. Feeding diets with low Zn reduced the BWG of birds during $1-10(P<0.001)$ and $1-24(P$ $<0.02)$ days of age. At $d 24$, the BWG was higher $(P<0.02)$ in diets with phytase than in unsupplemented diets (1051 vs $1005 \mathrm{~g} / \mathrm{bird})$. The FCR of birds was not affected $(P>0.05)$ by $\mathrm{Zn}$, phytase or their interaction.

High Fe diet with phytase supplementation increased $(\mathrm{Zn} \times$ phytase, $P<0.01)$ the Fe deposition in the liver (Table 5). Birds fed high-Zn diet showed the highest $(P<0.02) Z n$ content in liver $(77.8 \mu \mathrm{g} / \mathrm{g})$ than those on low or mid-Zn diet $(70.8$ and $72.7 \mu \mathrm{g} / \mathrm{g}$, respectively). There was no phytase effect on the mineral contents of the liver. The $\mathrm{Zn}$ and phytase interaction was not significant for $\mathrm{Cu}$ and $\mathrm{Mn}$ content of liver.

Table 4 Effects of varying levels of dietary $\mathrm{Zn}$ with or without microbial phytase on feed intake $(\mathrm{FI})$ and body weight gain (BWG), and feed conversion ratio (FCR) of broilers from day 0 to $35^{1}$

\begin{tabular}{|c|c|c|c|c|c|c|c|c|c|c|}
\hline \multicolumn{2}{|c|}{ Treatment } & \multicolumn{3}{|c|}{ FI (g/bird) } & \multicolumn{3}{|c|}{ BWG (g/bird) } & \multicolumn{3}{|c|}{ FCR } \\
\hline $\mathrm{Zn}$ & Phytase & $1-10 d$ & $1-24 d$ & $1-35 d$ & $1-10 d$ & $1-24 d$ & $1-35 d$ & $1-10 d$ & $1-24 d$ & $1-35 d$ \\
\hline \multirow[t]{2}{*}{ Low } & None & 268 & 1383 & 4481 & 218 & 1000 & 2402 & 1.24 & 1.37 & 1.87 \\
\hline & Plus & 255 & 1404 & 4382 & 212 & 1035 & 2498 & 1.20 & 1.36 & 1.75 \\
\hline \multirow[t]{2}{*}{ Mid } & None & 272 & 1465 & 4260 & 223 & 965 & 2468 & 1.22 & 1.52 & 1.73 \\
\hline & Plus & 277 & 1450 & 4408 & 228 & 1039 & 2417 & 1.21 & 1.40 & 1.84 \\
\hline \multirow[t]{2}{*}{ High } & None & 281 & 1425 & 4501 & 239 & 1051 & 2386 & 1.18 & 1.40 & 1.89 \\
\hline & Plus & 275 & 1456 & 4373 & 239 & 1078 & 2501 & 1.16 & 1.30 & 1.75 \\
\hline SEM & & 1.50 & 6.87 & 34.7 & 1.03 & 4.93 & 12.9 & 0.01 & 0.01 & 0.01 \\
\hline \multicolumn{11}{|c|}{ Source of variation } \\
\hline \multicolumn{2}{|c|}{$\mathrm{Zn}$} & $<0.05$ & 0.092 & 0.74 & $<0.001$ & $<0.02$ & 0.99 & 0.14 & 0.13 & 0.83 \\
\hline \multicolumn{2}{|c|}{ Phytase } & 0.376 & 0.610 & 0.825 & 0.989 & $<0.02$ & 0.243 & 0.373 & 0.181 & 0.381 \\
\hline \multicolumn{2}{|c|}{$\mathrm{Zn} \times$ phytase } & 0.350 & 0.707 & 0.594 & 0.491 & 0.501 & 0.270 & 0.856 & 0.399 & 0.127 \\
\hline
\end{tabular}

${ }^{1}$ Means were obtained from 6 replicate cages of 6-8 birds per cage;

SEM - Standard error of mean.

Table 5 Effects of varying levels of dietary $\mathrm{Zn}$ with or without phytase on liver mineral contents $(\mu \mathrm{g} / \mathrm{g})$ of broilers $(24 \mathrm{~d})^{1}$

\begin{tabular}{llcccc}
\hline Zn & Phytase & $\mathbf{F e}$ & $\mathbf{Z n}$ & $\mathbf{C u}$ & $\mathbf{M n}$ \\
\hline \multirow{2}{*}{ Low } & None & $384.3^{\mathrm{bc}}$ & 72.0 & 10.3 & 9.4 \\
& Plus & $321.1^{\mathrm{c}}$ & 69.6 & 9.0 & 10.3 \\
Mid & None & $421.3^{\mathrm{b}}$ & 73.5 & 10.2 & 10.2 \\
& Plus & $345.3^{\mathrm{bc}}$ & 71.8 & 10.6 & 8.5 \\
High & None & $422.4^{\mathrm{b}}$ & 79.3 & 10.6 & 11.1 \\
& Plus & $550.1^{\mathrm{a}}$ & 76.4 & 10.2 & 10.3 \\
SEM & 7.54 & 0.53 & 0.17 & 0.16 \\
Source of variation & & & & \\
Zn & $<0.001$ & $<0.02$ & 0.531 & 0.192 \\
Phytase & 0.884 & 0.214 & 0.492 & 0.355 \\
Zn x phytase & $<0.01$ & 0.963 & 0.583 & 0.191
\end{tabular}

\footnotetext{
${ }^{a-c}$ Means within a column without common superscript are significantly different at the level shown;

${ }^{1}$ Means were obtained from 6 replicate cages of 2 birds per cage; SEM - Standard error of mean.
} 
The interaction between $\mathrm{Zn}$ and phytase significantly influenced the ileal digestibility of $\mathrm{P}, \mathrm{Mg}, \mathrm{Fe}$ and $\mathrm{Zn}$ (Table 6). Phytase supplementation to high-Zn diets improved the digestibility of $\mathrm{P}(P<0.001)$ but reduced the $\mathrm{Mg}(P<0.001)$, Fe $(P<0.02)$, and $\mathrm{Zn}(P<0.01)$ digestibility. Birds fed phytase supplemented diets had poorer $(P<0.01)$ Ca digestibility $(0.41$ vs 0.50$)$ than those fed unsupplemented diets. There was no effect of $Z \mathrm{n}$, phytase and their interaction on ileal digestibility of $\mathrm{N}$.

The retention of $\mathrm{Zn}$ was significantly affected by the interaction between $\mathrm{Zn}$ and phytase (Table 7). Total tract retention of $Z n$ was reduced $(P<0.001)$ in birds fed high-Zn diet with phytase supplementation. There was a tendency to increase the retention of $\mathrm{N}(P=0.096)$ and $\mathrm{Ca}(P=0.085)$ in birds received phytasesupplemented high-Zn diets. Diets with phytase supplementation improved $(P<0.01)$ the $\mathrm{P}$ retention better than enzyme unsupplemented diets (0.50 vs 0.41).

Table 6 Influence of different levels of dietary $\mathrm{Zn}$ with or without microbial phytase on the ileal digestibility of minerals at $24 \mathrm{~d}$ of age ${ }^{1}$

\begin{tabular}{llllclll}
\hline Zn & Phytase & $\mathbf{N}$ & $\mathbf{C a}$ & $\mathbf{P}$ & $\mathbf{M g}$ & $\mathbf{F e}$ & $\mathbf{Z n}$ \\
\hline \multirow{2}{*}{ Low } & None & 0.81 & 0.53 & $0.42^{\mathrm{c}}$ & $0.11^{\mathrm{c}}$ & $0.40^{\mathrm{c}}$ & $0.20^{\mathrm{bc}}$ \\
& Plus & 0.81 & 0.42 & $0.45^{\mathrm{bc}}$ & $0.24^{\mathrm{b}}$ & $0.52^{\mathrm{b}}$ & $0.24^{\mathrm{b}}$ \\
Mid & None & 0.83 & 0.50 & $0.51^{\mathrm{abc}}$ & $0.21^{\mathrm{bc}}$ & $0.47^{\mathrm{bc}}$ & $0.26^{\mathrm{b}}$ \\
& Plus & 0.82 & 0.44 & $0.52^{\mathrm{ab}}$ & $0.20^{\mathrm{bc}}$ & $0.46^{\mathrm{bc}}$ & $0.20^{\mathrm{bc}}$ \\
High & None & 0.83 & 0.53 & $0.55^{\mathrm{b}}$ & $0.34^{\mathrm{a}}$ & $0.56^{\mathrm{a}}$ & $0.35^{\mathrm{a}}$ \\
& Plus & 0.82 & 0.36 & $0.62^{\mathrm{a}}$ & $0.10^{\mathrm{c}}$ & $0.48^{\mathrm{bc}}$ & $0.16^{\mathrm{c}}$ \\
SEM & & 0.003 & 0.01 & 0.01 & 0.01 & 0.01 & 0.01 \\
Source of variation & & & & & & \\
Zn & 0.857 & 0.487 & 0.230 & 0.622 & 0.120 & 0.254 \\
Phytase & 0.130 & $<0.01$ & 0.195 & 0.254 & 0.613 & $<0.02$ \\
Zn x phytase & 0.192 & 0.527 & $<0.001$ & $<0.001$ & $<0.02$ & $<0.01$ \\
\hline
\end{tabular}

${ }^{\mathrm{a}-\mathrm{c}}$ Means within a column without common superscript are significantly different at the level shown;

${ }^{1}$ Means were obtained from 6 replicate cages of 2 birds per cage; SEM - Standard error of mean.

Table 7 Effects of different levels of dietary $\mathrm{Zn}$ with or without microbial phytase on the total tract retention of minerals in broilers $(22-24 d)^{1}$

\begin{tabular}{lllllll}
\hline Zn & Phytase & $\mathbf{N}$ & $\mathbf{C a}$ & $\mathbf{P}$ & $\mathbf{F e}$ & $\mathbf{Z n}$ \\
\hline \multirow{2}{*}{ Low } & None & 0.66 & 0.39 & 0.42 & 0.47 & $0.11^{\mathrm{cd}}$ \\
& Plus & 0.55 & 0.31 & 0.45 & 0.52 & $0.24^{\mathrm{ab}}$ \\
Mid & None & 0.58 & 0.23 & 0.35 & 0.47 & $0.22^{\mathrm{b}}$ \\
& Plus & 0.61 & 0.41 & 0.51 & 0.45 & $0.17^{\mathrm{bc}}$ \\
High & None & 0.69 & 0.38 & 0.46 & 0.56 & $0.32^{\mathrm{a}}$ \\
& Plus & 0.66 & 0.44 & 0.55 & 0.48 & $0.03^{\mathrm{d}}$ \\
SEM & & 0.01 & 0.01 & 0.01 & 0.001 & 0.001 \\
Source of variation & & & & & \\
Zn & & 0.05 & 0.219 & 0.072 & 0.185 & $<0.001$ \\
Phytase & 0.163 & 0.210 & $<0.01$ & 0.595 & $<0.01$ \\
Zn x phytase & 0.096 & 0.085 & 0.150 & 0.218 & $<0.001$ \\
\hline
\end{tabular}

${ }^{a-d}$ Means within a column without common superscript are significantly different at the level shown; Means were obtained from 6 replicate cages of 6 birds per cage; SEM - Standard error of mean. 
The length, width, breaking strength, ash and mineral content of tibia bone of birds were unaffected $(P$ $>0.05$ ) by different levels of $\mathrm{Zn}$ and phytase (Table 8). The interaction between $\mathrm{Zn}$ and phytase was significant only for tibia Fe concentration. Birds fed high-Zn diet with phytase showed the highest $(P<0.05)$ accumulation of $\mathrm{Fe}$ in tibia. Although not significant, $\mathrm{Zn}$ deposition in tibia tended to be highest $(\mathrm{p}=0.082)$ in birds fed diets containing the mid-level of $\mathrm{Zn}$. There was no significant effect of $\mathrm{Zn}$, phytase or their interaction on different blood variables (data not shown).

There were significant interactions between $\mathrm{Zn}$ and phytase for protein and the activities of enzymes in the jejunum (Table 9). Phytase supplemented to high-Zn diets improved the protein content $(P<0.01)$ and activities of AP and Ca-Mg-ATPase $(P<0.001)$ in the jejunum of 24-d old birds. Birds fed mid-Zn diets with phytase supplementation showed the highest $(P<0.001)$ activity of Ca-ATPase and Mg-ATPase in the jejunum mucosa.

Table 8 Effects of varying levels of dietary $\mathrm{Zn}$ with or without phytase on tibia morphometric parameters, breaking strength (BBS), ash, and mineral contents of broilers at $24 \mathrm{~d}$ of age ${ }^{1}$

\begin{tabular}{|c|c|c|c|c|c|c|c|c|c|}
\hline Zn & Phytase & $\begin{array}{l}\text { Length } \\
(\mathrm{mm})\end{array}$ & $\begin{array}{l}\text { Width } \\
(\mathrm{mm})\end{array}$ & $\begin{array}{l}\text { BBS } \\
\text { (N) }\end{array}$ & Tibia ash\% & $\mathrm{Ca} \%$ & $\mathrm{P} \%$ & $\begin{array}{c}\mathrm{Fe} \\
\mathrm{mg} / \mathrm{kg}\end{array}$ & $\begin{array}{c}\mathrm{Zn} \\
\mathrm{mg} / \mathrm{kg}\end{array}$ \\
\hline \multirow[t]{2}{*}{ Low } & None & 73.0 & 7.3 & 276.3 & 49.1 & 38.8 & 18.0 & $285.7^{\mathrm{ab}}$ & 349.1 \\
\hline & Plus & 74.3 & 7.6 & 323.3 & 52.1 & 39.5 & 18.0 & $298.5^{\mathrm{ab}}$ & 369.5 \\
\hline \multirow[t]{2}{*}{ Mid } & None & 74.2 & 7.3 & 284.9 & 47.9 & 39.1 & 18.0 & $310.0^{b}$ & 398.9 \\
\hline & Plus & 73.9 & 7.4 & 287.8 & 46.9 & 39.0 & 17.9 & $279.3^{\mathrm{ab}}$ & 407.8 \\
\hline \multirow[t]{2}{*}{ High } & None & 72.7 & 7.2 & 277.6 & 47.8 & 39.5 & 18.0 & $275.4^{\mathrm{ab}}$ & 359.7 \\
\hline & Plus & 74.7 & 7.6 & 277.0 & 48.9 & 39.1 & 18.0 & $315.2^{\mathrm{a}}$ & 361.5 \\
\hline SEM & & 0.22 & 0.04 & 3.27 & 0.62 & 0.12 & 0.06 & 3.20 & 5.06 \\
\hline \multicolumn{10}{|c|}{ Source of variation } \\
\hline \multicolumn{2}{|c|}{$\mathrm{Zn}$} & 0.888 & 0.700 & 0.281 & 0.471 & 0.871 & 0.906 & 0.969 & 0.082 \\
\hline \multicolumn{2}{|c|}{ Phytase } & 0.208 & 0.092 & 0.157 & 0.636 & 0.811 & 0.839 & 0.515 & 0.559 \\
\hline \multicolumn{2}{|c|}{ Zn $\times$ phytase } & 0.438 & 0.656 & 0.179 & 0.748 & 0.545 & 0.858 & $<0.05$ & 0.909 \\
\hline
\end{tabular}

${ }^{\mathrm{a}, \mathrm{b}}$ Means within a column without common superscript are significantly different at the level shown

${ }^{1}$ Means were obtained from 6 replicate cages of 2 birds per cage; SEM - Standard error of mean.

Phytase supplementation to diets containing mid to high-levels of $\mathrm{Zn}$ diets increased the ME $(\mathrm{Zn} x$ phytase, $P<0.01$ ) content of diets (Table 10). The $\mathrm{Zn}$ and phytase interaction was significant for MEl and NEp. The MEI $(P<0.01)$ and NEp $(P<0.01)$ were higher in birds that consumed diets containing mid or high levels of $\mathrm{Zn}$ with phytase supplementation. Heat production was not affected by $\mathrm{Zn}$, phytase or their interaction. Increasing $\mathrm{Zn}$ levels in diets improved $(P<0.001)$ the REp and protein deposition rate in the tissue. Phytase supplemented to low- $Z n$ diet reduced the $(Z n \times$ phytase, $P<0.01)$ the energy retention as fat (REf). Birds that consumed phytase-supplemented diets with mid or high levels of $\mathrm{Zn}$ deposited fat $(\mathrm{Zn} x$ phytase, $P<0.01)$ and energy $(\mathrm{Zn} \times$ phytase, $P<0.01)$ at a faster rate than other groups of birds. The efficiency of ME utilization for energy (KRE), fat (KREf), and protein (KREp) deposition were $0.75-0.84,0.16$ - 0.18 , and $0.41-0.46$, respectively, and were not affected by $\mathrm{Zn}$, phytase, or their interaction.

\section{Discussion}

In the current study, birds given the low-Zn diet showed reduced feed intake and body weight gain at 24 days of age. The poor body weight gain can be attributed to low feed intake, which is associated with a low dietary $\mathrm{Zn}$ level. Moreover, the weight gain of birds depends on effective utilisation of consumed feed and its subsequent use in cell proliferation; mainly in the muscle. Therefore, $\mathrm{Zn}$ deficiency may cause retarded growth and poor weight gain due to its role in DNA/RNA synthesis and carbohydrate, fat or protein metabolism (Wu and Wu, 1987). Previous studies (Bao et al., 2007; Ao et al., 2011) have reported the same trend in birds fed a low or deficient $\mathrm{Zn}$ diet. However, the exact mechanism by which dietary $\mathrm{Zn}$ influences feed intake is still unclear but it can be related to satiety regulation. It has been reported that $\mathrm{Zn}$-deficient diets could increase the gene expression of mRNA for cholecystokinin (CCK) production in the intestine, which negatively affects the appetite of animals (Blanchard \& Cousins, 2000; Mcdonald, 2011). 
Table 9 Effects of varying levels of dietary $\mathrm{Zn}$ with or without phytase on jejunal protein and enzyme activity of broilers at $24 \mathrm{~d}$ of age ${ }^{1}$

\begin{tabular}{|c|c|c|c|c|c|c|}
\hline Zn & Phytase & Protein & AP & Ca-Mg-ATPase & Ca-ATPase & Mg-ATPase \\
\hline & & $(\mathrm{mg} / \mathrm{g})$ & $\mu \mathrm{m} / \mathrm{mg}$ protein/min & \multicolumn{3}{|c|}{$\mathrm{nmol} / \mathrm{mg}$ protein/min } \\
\hline \multirow[t]{2}{*}{ Low } & None & $73.0^{\mathrm{b}}$ & $1.23^{c}$ & $173.0^{b}$ & $72.6^{\mathrm{b}}$ & $148.9^{b}$ \\
\hline & Plus & $73.7^{\mathrm{b}}$ & $1.69^{b}$ & $154.5^{\mathrm{c}}$ & $70.8^{\mathrm{b}}$ & $150.7^{b}$ \\
\hline \multirow[t]{2}{*}{ Mid } & None & $69.2^{\mathrm{bc}}$ & $1.48^{\mathrm{b}}$ & $148.9^{c}$ & $72.6^{\mathrm{b}}$ & $129.1^{c}$ \\
\hline & Plus & $71.4^{\mathrm{b}}$ & $1.52^{\mathrm{b}}$ & $126.0^{d}$ & $84.5^{\mathrm{a}}$ & $184.1^{\mathrm{a}}$ \\
\hline \multirow[t]{2}{*}{ High } & None & $63.3^{c}$ & $1.61^{\mathrm{b}}$ & $153.4^{c}$ & $72.2^{b}$ & $149.9^{b}$ \\
\hline & Plus & $83.5^{\mathrm{a}}$ & $1.97^{\mathrm{a}}$ & $200.1^{a}$ & $73.1^{\mathrm{b}}$ & $152.1^{b}$ \\
\hline SEM & & 0.52 & 0.17 & 1.21 & 0.26 & 11.57 \\
\hline \multicolumn{7}{|c|}{ Source of variation } \\
\hline \multicolumn{2}{|c|}{$\mathrm{Zn}$} & $<0.001$ & $<0.001$ & $<0.001$ & $<0.001$ & 0.478 \\
\hline \multicolumn{2}{|c|}{ Phytase } & 0.850 & 0.424 & 0.679 & $<0.001$ & $<0.001$ \\
\hline \multicolumn{2}{|c|}{ Zn x phytase } & $<0.01$ & $<0.001$ & $<0.001$ & $<0.001$ & $<0.001$ \\
\hline
\end{tabular}

Table 10 Effects of varying levels of dietary $\mathrm{Zn}$ with or without phytase on net energy parameters ${ }^{1}$

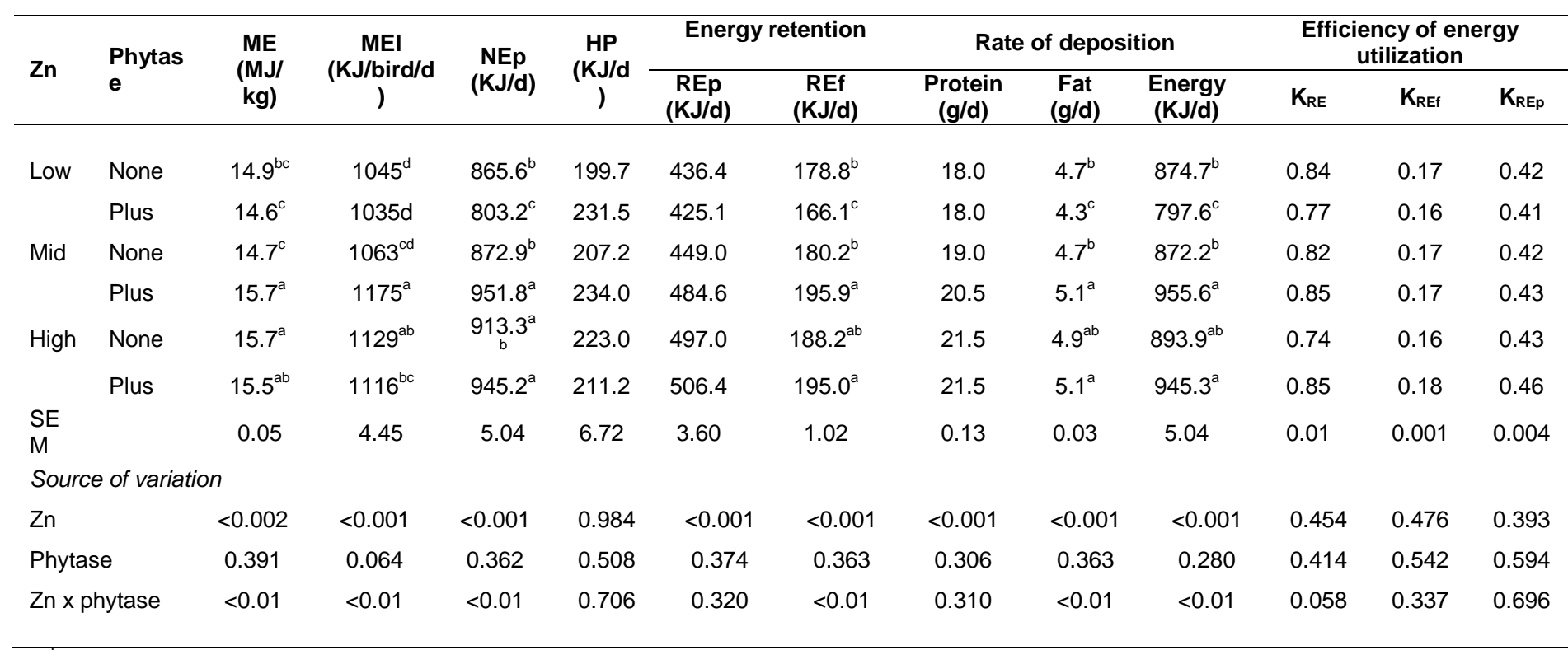

\footnotetext{
${ }^{\mathrm{a}-\mathrm{d}}$ Means within a column without common superscript are significantly different at the level shown.

${ }^{1}$ Means were obtained from 6 replicate cages of 2 birds per cage;

NEp - Net energy for production; HP- Heat production;

REp - Energy retained as protein;

REf - Energy retained as fat;

$\mathrm{K}_{\mathrm{RE}}$ - Efficiency of ME use for energy retention;

$\mathrm{K}_{\mathrm{REf}}$ - Efficiency of ME use for fat retention;

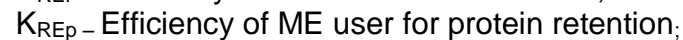

SEM - Standard error of mean.
}

In contrast, several studies (Salim et al., 2011; Salim et al., 2012; Štenclová et al., 2016) have reported that the overall performance of birds was not influenced by a varying concentration or source of $\mathrm{Zn}$. The discrepancy may be due to the use of different amounts and sources of $\mathrm{Zn}$ in these experiments. 
Different levels of $Z n$ have no effect on FCR, a finding which is supported by previous study (Roy et al., 2014).

Phytase supplementation had no effect on FI but improved the BWG of birds, irrespective of Zn level. However, as a mineral nutrient matrix was applied with phytase supplementation and the dietary mineral content consequently reduced, an improvement in performance was not expected. This indicates that the diet was limiting in minerals such as $\mathrm{P}$ or $\mathrm{Ca}$, or that phytase released other nutrients, possibly including energy and amino acids. This result also suggests that $Z n$ levels used in the present study did not reduce the ability of the phytase to degrade phytate. As feed intake of birds was unaffected by phytase supplementation, the improved BWG of the same group of birds could be interpreted as being a consequence of the release of phytate-bound minerals and other nutrients by phytase. The beneficial effect of phytase on BWG has also been reported in previous studies (Dilger et al., 2004; Akter et al., 2017). The lack of response to phytase on FCR is in agreement with Roy et al. (2014).

An improvement in $\mathrm{P}$ utilization due to phytase supplementation was observed in diets containing $\mathrm{Zn}$ at a level of $40-50 \mathrm{mg} / \mathrm{kg}$ of diet. In contrast, supplementation of phytase in the high-Zn diet $(50 \mathrm{mg} / \mathrm{kg})$ reduced the digestibility of $\mathrm{Fe}$ and $\mathrm{Zn}$, which is consistent with their low retention. The significant interaction between $\mathrm{Zn}$ and phytase in nutrient utilization ( $\mathrm{Fe}$ and $\mathrm{Zn}$ ) may indicate the possible formation of a $\mathrm{Zn}$ phytate complex in the GIT of birds, which hindered phytate hydrolysis by phytase and limited the bioavailability of these minerals. Therefore, it can be assumed that phytase is less likely to release phytatebound minerals at high dietary $\mathrm{Zn}$ concentration. However, body weight gain and tibia bone development have been considered to be the most sensitive criteria for assessing phytase benefit. As there was no effect of high-Zn diet with added phytase on bird performance and bone development, the observed significant negative interaction between high $\mathrm{Zn}$ and phytase on $\mathrm{Fe}$ and $\mathrm{Zn}$ utilization could be due to a unique absorption and reabsorption pattern of trace minerals in the GIT of broilers, leading to under- or overestimation of the utilization of these minerals (Underwood \& Shuttle, 1999b; Bao et al., 2007).

The interaction between $\mathrm{Zn}$ and phytase significantly influenced the different variables of energy utilization. Phytase supplementation with mid or high Zn diet significantly improved ME, MEI, NEp, REp, REf and $\mathrm{K}_{\mathrm{RE}}$. The increase in MEI may be the result of higher feed intake, which is correlated with NEp. This is because, with a greater consumption of feed, there is a greater energy intake, which can be used for production rather than maintenance (Pirgozliev et al., 2011). Along with more feed consumption and the highest body weight gain, this group of birds showed increased utilization of different nutrients. It is possible that the release of phytate-bound nutrients by phytase increased feed intake due to high dietary $\mathrm{Zn}$ improving the energy utilization of birds. Moreover, the available extra energy is retained as fat or protein in the body, which contributes to improved weight gain. This relationship between improved BWG and an increased amount of energy deposited in tissues validates NEp as a more sensitive measure of energy utilization than ME.

It has been reported that fat retention increases in birds older than 35 days of age (Boekholt et al., 1994). In the present study birds deposited more energy as protein than as fat during the period of $0-24 \mathrm{~d}$, which indicates better utilization of energy as protein and hence production of lean meat. Although the efficiency of ME retention as energy, fat and protein was unaffected by treatment differences, the $\mathrm{K}_{\mathrm{RE}}$ value was higher in the present study than in the study of Olukosi et al. (2008). This may be due to differences in ME intake between the studies.

The accumulation of trace minerals in different tissues, for example the tibia, liver and plasma, is considered to be a good measure of the mineral status of birds (Salim et al., 2012). The concentration of Fe in tibia bone and liver was greater in birds that consumed the high-Zn diet with phytase supplementation. The liver is the main storage site of $\mathrm{Fe}$, and it is possible that after $\mathrm{Fe}$ saturation of the liver, excess $\mathrm{Fe}$ moves to the tibia. This relocation of $\mathrm{Fe}$ is the result of the very limited amounts of Fe that are excreted through urine or sweat. Most of the excess $\mathrm{Fe}$ is usually excreted via sloughing of intestinal enterocytes (Cao et al., 1996). Therefore, the observed high concentration of Fe in the tibia and liver in the present study could be due to reduced excretion of $\mathrm{Fe}$. Besides, the greater $\mathrm{Zn}$ concentration in the liver in the present study with mid to higher $\mathrm{Zn}$ diet partly supports the findings of Sunder et al. (2013). These authors reported that hepatic accumulation of $\mathrm{Zn}$ started to increase in birds fed diet with $160 \mathrm{mg} \mathrm{Zn/kg}$ and indicated that comparatively higher $\mathrm{Zn}$ supplementation is required to obtain a significant increase of this mineral in liver. There was no effect of phytase on accumulation of $\mathrm{Zn}$ in the liver and tibia, which is in accordance with other studies (Mohanna \& Nys 1999a; Ao et al., 2007).

Tibia $\mathrm{Zn}$ concentration tended to increase in birds offered the diet with mid-level $(40 \mathrm{mg} / \mathrm{kg}) \mathrm{Zn}$ supplementation. This is partly in agreement with Mwangi et al. (2017) who reported that supplementing diet with $40 \mathrm{mg} / \mathrm{kg} \mathrm{Zn}$ increased the tibia Zn concentration compared to a diet with $8 \mathrm{mg} \mathrm{Zn/kg}$. According to Vieira et al. (2013) supplementation of 40 and $100 \mathrm{mg} \mathrm{Zn/kg} \mathrm{of} \mathrm{diets} \mathrm{had} \mathrm{no} \mathrm{statistically} \mathrm{significant} \mathrm{difference}$ in tibia Zn deposition. Similarly, previous study (Ao et al., 2011) reported that tibia Zn concentration starts to 
increase when dietary $\mathrm{Zn}$ ranges from 45 to $70 \mathrm{mg} / \mathrm{kg}$. It has been reported that $40 \mathrm{mg}$ of $\mathrm{Zn} / \mathrm{kg}$ diet is adequate for optimizing BWG (Mohanna \& Nys, 1999a), whereas increasing Zn level beyond this level causes an increased deposition in the tibia, but this plateaued at a level of $48 \mathrm{mg} \mathrm{Zn/} \mathrm{kg} \mathrm{(Bao} \mathrm{et} \mathrm{al.,} \mathrm{2007).}$

In this study, the AP activity in the jejunal mucosa was reduced at low dietary $\mathrm{Zn}$, which was counterbalanced by phytase supplementation. The release of $\mathrm{Zn}$ from phytate-mineral complex can be the possible cause of increased activity of AP in phytase-supplemented diets. According to Ghalehkandi et al. (2011) the activity of AP was higher in the intestine of male broilers fed diets containing $50-100 \mathrm{mg} \mathrm{Zn} / \mathrm{kg}$ than in birds fed a diet without $\mathrm{Zn}$ supplementation. These authors found that the growth of intestinal coliform bacteria, responsible for damaging the intestinal mucosa and reduction of the absorption and digestion of nutrients, was inhibited by $\mathrm{Zn}$. Further, $\mathrm{Zn}$ is required for maintaining the stability of AP, and deficiency of this mineral leads to poor activity of the enzyme (Reinhold et al., 1969; Cho et al., 2007). Phytase improved the activities of Ca-ATPase and Mg-ATPase in jejunal mucosa of birds on diets with a mid-level of $\mathrm{Zn}$, which indicates increased absorption of $\mathrm{Ca}$ and therefore increased utilization (Bronner, 2003).

\section{Conclusion}

The results of the present study indicate that microbial phytase is effective in improving the performance and nutrient utilization of birds that consume diets with $40-50 \mathrm{mg} \mathrm{Zn} / \mathrm{kg}$. Improved growth performance and nutrient and energy utilization was mainly observed in birds given the highest $\mathrm{Zn}$ diets, irrespective of phytase supplementation. This suggests that using $50 \mathrm{mg} \mathrm{Zn/kg}$ of diet optimizes performance of birds and does not inhibit phytase activity. As most commercial poultry diets contain more than $100 \mathrm{mg}$ $\mathrm{Zn} / \mathrm{kg}$ of diet, further study is warranted to investigate whether this higher concentration of $\mathrm{Zn}$ has any effect on phytase activity or utilisation of other nutrients.

\section{Acknowledgements}

The study was funded by AB Vista, UK and University of New England, Australia.

\section{Authors' Contribution}

MA, PAI and HG were in charge of study design. MA carried out the animal experiment and did all laboratory and statistical analysis. MA wrote the first draft of manuscript. PAI and HG revised the manuscript.

\section{Conflicts of Interest Declaration}

The authors declare that they have no competing interests.

\section{References}

Akter, M., Graham, H. \& lji, P.A., 2015. Interactions between phytase and different dietary minerals in in vitro systems. J. Food. Agri. 13, 38-44.

Akter, M., Iji, P. A. \& Graham, H., 2017. Increased iron level in phytase-supplemented diets reduces performance and nutrient utilisation in broiler chickens. Br. Poult. Sci. 1-9.

Anderson, D.L. \& Henderson, L.J., 1986. Sealed chamber digestion for plant nutrient analysis. Agron. J. 78, 937-938.

Ao, T., Pierce, J.L., Pescatore, A.J., Cantor, A.H., Dawson, K.A., Ford, M.J. \& Paul, M., 2011. Effects of feeding different concentration and forms of zinc on the performance and tissue mineral status of broiler chicks. Br. Poult. Sci. 52, 466-471.

Ao, T., Pierce, J.L., Pescatore, A.J., Cantor, A.H., Dawson, K.A., Ford, M.J. \& Shafer, B.L., 2007. Effects of organic zinc and phytase supplementation in a maize-soybean meal diet on the performance and tissue zinc content of broiler chicks. Br. Poult. Sci. 48, 690-695.

Aviagen, 2009. Ross 308 broiler nutrition specification. Available at http://en.aviagen.com/assets/Tech Center/Ross Broiler/Ross Nutrition Supplement.pdf

Blanchard, R. K. \& Cousins, R. J., 2000. Regulation of intestinal gene expression by dietary zinc: Induction of uroguanylin mRNA by zinc deficiency. J. Nutr. 130, 1393S-1398S.

Bao, Y.M., Choct, M.. lji, P.A. \& Bruerton, K., 2007. Effect of organically complexed copper, iron, manganese, and zinc on broiler performance, mineral excretion, and accumulation in tissues. J. Appl. Poult. Res. 16, 448-455.

Boekholt, H.A, van der Grinten, P., Schreurs, V.V., Los, M.J. \& Leffering, C.P., 1994. Effect of dietary energy restriction on retention of protein, fat and energy in broiler chickens. Br. Poult. Sci. 35, 603-614.

Bronner, F., 2003. Mechanisms of intestinal calcium absorption. J. Cell. Biochem. 88, 387-393.

Burrell, A.L., Dozier, W.A., Davis, A.J., Compton, M.M., Freeman, M.E., Vendrell, P.F. \& Ward, T.L., 2004. Responses of broilers to dietary zinc concentrations and sources in relation to environmental implications. Br. Poult. Sci. 45, 225-263.

Cabahug, S., Ravindran, V., Selle, P.H. \& Bryden, W.L., 1999. Response of broiler chickens to microbial phytase supplementation as influenced by dietary phytic acid and non-phytate phosphorus contents. I. Effects on bird performance and toe ash. Br. Poult. Sci. 40, 660-666. 
Cao, J., Luo, X.G., Henry, P.R., Ammerman, C.B., Littell, R.C. \& Miles, R.D. 1996. Effect of dietary iron concentration, age, and length of iron feeding on feed intake and tissue iron concentration of broiler chicks for use as a bioassay of supplemental iron sources. Poult. Sci. 75: 495-504.

Cho, Y-E., Lomeda, R-AR., Ryu, S-H., Sohn, H-Y., Shin, H-I., Beattie, J. H. \& Kwun, I-S., 2007. Zinc deficiency negatively affects alkaline phosphatase and the concentration of $\mathrm{Ca}, \mathrm{Mg}$ and $\mathrm{P}$ in rats. Nutr. Res. Pract. 2, 113119.

Dilger, R.N., Onyango, E.M., Sands, J.S \& Adeola, O., 2004. Evaluation of Microbial Phytase in Broiler Diets. Poult. Sci. 83, 962-970.

Dozier, W.A.3 ${ }^{\text {rd }}$., , Davis, A.J., Freeman, M.E. \& Ward, T.L., 2003. Early growth and environmental implications of dietary zinc and copper concentrations and sources on broiler chicks. Br. Poult. Sci. 44, 726-31.

Ghalehkandi, J.G., Karamouz, H., Shahriar, H.A., Nazhad, H.Z.A., Beheshti, R. \& Karimi, N., 2011. Effect of inorganic zinc supplement on activity of alkaline phosphatase enzyme as an index of mucosal functional in small intestine of male broile.rs. Am. Eurasian. J. Agric. Environ. Sci. 11, 622-625.

Kornegay, E.T., 2001. Digestion of phosporus and other nutrients: The role of phytases and factors influening their activity. In: Enzymes in Farm Animal Nutrtion. Eds. Bedford, M. R. \& Partridge, G. G., CAB International, UK. pp. 237-271.

Kfoury, G. A., Reinhold, J. G. \& Simonian, S. J., 1968. Enzyme activities in tissues of zinc-deficient rats. J. Nutr. 95, 102110.

Larbier, M. \& Leclercq, B., 1992. Energy metabolism. In: Nutrition and Feeding of Poultry. Eds. Wiseman, J., Nottingham University Press, Nottingham. pp. 47-73.

Maenz, D.D., Engele-Schaan., C.M., Newkirk., R..W. \& Classen., H.L., 1999. The effect of minerals and mineral chelators on the formation of phytase-resistant and phytase-susceptible forms of phytic acid in solution and in a slurry of canola meal. Anim. Feed Sci. Tech. 81, 177-192.

McDonald, P., Edwards, R. A., Greenhalgh, J. F. D., Morgan, C. A., Sinclair, L. A. \& Wilkinson, R. G., 2011. Animal Nutrition. Pearson, Harlow, UK. pp. 440.

Minitab, 2010. Minitab 16 statistical software. Minitab Inc., State College, Pennsylvania, USA.

Mohanna, C. \& Nys, Y., 1999a. Changes in zinc and manganese availability in broiler chicks induced by vegetal and microbial phytases. Anim. Feed Sci. Tech. 77, 241-253.

Mohanna, C. \& Nys, Y., 1999b. Effect of dietary zinc content and sources on the growth, body zinc deposition and retention, zinc excretion and immune response in chickens. Br. Poult. Sci. 40, 108-114.

Mwangi, S., Timmons, J., Ao, T., Paul, M., Macalintal, L., Pescatore, A., Cantor, A., Ford, M. \& Dawson, K. A., 2017. Effect of zinc imprinting and replacing inorganic zinc with organic zinc on early performance of broiler chicks. Poult. Sci. 96, 861-868.

NRC, 1994. Nutrient Requirements of Poultry $\left(9^{\text {th }}\right.$ ed.). National Academy Press, Washington D.C., USA.

O'Dell, B.L. \& Savage, J.E., 1960. Effect of phytic acid on zinc availability. Proc. Soc. Exp. Biol. Med. 103, $304-305$.

Olukosi, O.A., Cowieson, A.J. \& Adeola, O., 2008. Energy utilization and growth performance of broilers receiving diets supplemented with enzymes containing carbohydrase or phytase activity individually or in combination. $\mathrm{Br}$. J. Nutr. 99, 682-690.

Pirgozliev, V., Bedford, M.R., Acamovic, T., Mares, P. \& Allymehr, M., 2011. The effects of supplementary bacterial phytase on dietary energy and total tract amino acid digestibility when fed to young chickens. Br. Poult. Sci. 52, 245-254.

Reddy, N.R., Sathe, S.K. \& Salunkhe, D.K., 1982. Phytates in legumes and cereals. Adv. Food Res. 28, 1-92.

Reinhold, J.G., Kfoury, G.A. \& Pharm, D., 1969. Zinc-dependent enzymes in zinc-depleted rats; intestinal alkaline phosphatase. Am. J. Clin.Nutr. 22, 1250-1263.

Roberson, K.D. \& Edwards, H.M., 1994. Effects of 1,25 dihydroxycholecalciferol and phytase on zinc utilization broiler chicks. Poult. Sci. 73, 1312-1326.

Roy, A., Mandal, G. P., Pal, K., Samanta, I., Biswas, P. \& Roy, B., 2014. Effect of zinc supplementation with or without phytase on performance, mineral accumulation in tissues and immune response of broiler. Anim. Nutr.Feed Tech. 14, 311-319.

Salim, H.M., Lee, H.R., Jo, C., Lee, S.K. \& Lee, B.D., 2011. Supplementation of graded levels of organic zinc in the diets of female broilers: effects on performance and carcase quality. Br. Poult. Sci.. 52, 606-612.

Salim, H.M., Lee, H.R., Jo, C., Lee, S.K. \& Lee, B.D., 2012. Effect of dietary zinc proteinate supplementation on growth performance, and skin and meat quality of male and female broiler chicks. Br. Poult. Sci. 53, 116-124.

Sebastian, S., Touchburn, S.P., Chavez, E.R. \& Lague, P.C., 1996. Efficacy of supplemental microbial phytase at different dietary calcium levels on growth performance and mineral utilization of broiler chickens. Poult. Sci. 75, $1516-1523$

Štenclová, H., Karásek, F., Št’astník, O., Zeman, L., Mrkvicová, E. \& Pavlata, L., 2016. The effect of reduced zinc levels on performance parameters of broiler chickens. Potravinarstvo, 10, 272-275.

Sunder, G. S., Ch., V. K., Panda, A. K., Raju, M. V. L. N. \& Rama Rao, S. V., 2013. Effect of supplemental organic zn and $\mathrm{mn}$ on broiler peroformnace, bone measures, tissue mineral uptake and immune response at 35 days of age. Curr. Res. Poult. Sci. 1, 1-11.

Sweeney, R.A., 1989. Generic combustion method for determination of crude protein in feeds: Collaborative study. J. AOAC. Int. 72, 770-774.

Thiel, U., Weigand, E., Hoppe, P.P. \& Schoner, F.J., 1993. Zinc retention of broiler chickens as effected by dietary supplementation of zinc and microbial phytase. In: Proceeding of the Eight International Symposium on Trace Elements in Man and Animals. Eds. Meissner, D. \& Mills, C. F., Verlag Media Touristik, Gersdorf. pp. 658-659. 
Underwood, E. J. \& Suttle, N. F., 1999a. Zn. In: The Mineral Nutrition of Livestock. Eds: Underwood, E. J. \& Suttle, N. F., (3rd ed.). CABI Publishing, Wallingford, UK. Pp. 477-512.

Underwood, E. J. \& Suttle, N. F., 1999b. The detection and correction of mineral imbalances in animals. In: The Mineral Nutrition of Livestock. Eds: Underwood, E. J. \& Suttle, N. F., (3rd ed.). CABI Publishing, Wallingford, UK. pp. 4768.

Vieira, M. M., Ribeiro, A. M. L., Kessler, A. M., Moraes, M. L., Kunrath, M. A. \& Ledur, V. S., 2013. Different sources of dietary zinc for broilers submitted to immunological, nutritional, and environmental challenge. J. Appl. Poult. Res. 22, 855-861.

Yi, Z., Kornegay, E.T. \& Denbow, D.M., 1996a. Effect of microbial phytase on nitrogen and amino acid digestibility and nitrogen retention of turkey poults fed corn-soybean meal diets. Poult. Sci. 75, 979-990.

Yi, Z., Kornegay, E.T. \& Denbow, D.M., 1996b. Supplemental microbial phytase improves zinc utilization in broilers. Poult. Sci. 75, 540-546.

Wu, F. Y. \& Wu, C. W., 1987. Zinc in DNA replication and transcription. Annu Rev Nutr. 7, 251-272. 